\title{
Neuropeptides in the gonads: from evolution to pharmacology
}

\author{
Nicolette L. McGuire ${ }^{1}$ and George E. Bentley ${ }^{1,2 *}$ \\ 1 Laboratory of Reproductive Neuroendocrinology, Department of Integrative Biology, University of California at Berkeley, Berkeley, CA, USA \\ 2 Helen Wills Neuroscience Institute, University of California at Berkeley, Berkeley, CA, USA
}

\section{Edited by:}

George J. Christ, Wake Forest

University School of Medicine, USA

\section{Reviewed by:}

Randy J. Nelson, The Ohio State

University, USA

Kazuyoshi Tsutsui, Waseda University,

Japan

*Correspondence:

George E. Bentley, 3060 VLSB \#3140, Department of Integrative Biology،

University of California at Berkeley,

Berkeley, CA 94720, USA.

e-mail:gb7@berkeley.edu

Vertebrate gonads are the sites of synthesis and binding of many peptides that were initially classified as neuropeptides. These gonadal neuropeptide systems are neither well understood in isolation, nor in their interactions with other neuropeptide systems. Further, our knowledge of the control of these gonadal neuropeptides by peripheral hormones that bind to the gonads, and which themselves are under regulation by true neuropeptide systems from the hypothalamus, is relatively meager. This review discusses the existence of a variety of neuropeptides and their receptors which have been discovered in vertebrate gonads, and the possible way in which such systems could have evolved. We then focus on two key neuropeptides for regulation of the hypothalamo-pituitary-gonadal axis: gonadotropin-releasing hormone $(\mathrm{GnRH})$ and gonadotropininhibitory hormone $(\mathrm{GnlH})$. Comparative studies have provided us with a degree of understanding as to how a gonadal $\mathrm{GnRH}$ system might have evolved, and they have been responsible for the discovery of $\mathrm{GnIH}$ and its gonadal counterpart. We attempt to highlight what is known about these two key gonadal neuropeptides, how their actions differ from their hypothalamic counterparts, and how we might learn from comparative studies of them and other gonadal neuropeptides in terms of pharmacology, reproductive physiology and evolutionary biology.

\section{Keywords: GnRH, GnIH, RFRP, testes, ovary, vertebrate, primate}

\section{INTRODUCTION}

"What's in a name? That which we call a rose

By any other name would smell as sweet."

Romeo and Juliet (Act 2, scene 2)

Neuropeptides appear to be appropriately named: they are peptides synthesized by neurons in the central nervous system. However, what matters is what they do, not what they are called, and we shall see in this review that neither the synthesis nor actions of neuropeptides are limited to the brain. This article focuses on "neuropeptides" in the gonads of vertebrates, with special emphasis on what we can learn from pharmacological experiments on gonadal tissue and then apply to our understanding of an animal's ecology in the wild.

Investigating the presence of neuropeptides in the gonads of a diverse array of species will provide us with information as to the possible evolutionary origins, adaptations, interactions and functions of what we are choosing to term "gonadal neuropeptide" systems. The conservation of localized gonadal regulation by gonadal neuropeptides across vertebrates has important implications for understanding the evolution, reproductive physiology and ecology of animals, along with the study and practice of reproductive health and medicine, both clinical and veterinary.

\section{NEUROPEPTIDES IN THE GONADS}

Many neuronally produced hormones with important endocrine, behavioral, sensory and autonomic roles in the vertebrate brain are also expressed by and may act directly within the gonads (Table 1; neuropeptide Y (NPY), Achi et al., 1995; bradykinin, Singh et al., 2007; corticotropin releasing factor (CRF), Huang et al., 1995; gonadotropin-releasing hormone (GnRH), Jones and Hsueh, 1981; Bahk et al., 1995; Pati and Habibi, 1998; gonadotropin-inhibitory hormone (GnIH), Hinuma et al., 2000; Bentley et al., 2008; kisspeptin, Castellano et al., 2006). The presence of neuropeptide receptors in the gonads: GnRH-R in mammals (Jones et al., 1980; Whitelaw et al., 1995; Schirman-Hildesheim et al., 2005)and fish, (von Schalburg et al., 1999; Bogerd et al., 2002); galanin receptor in mammals (Romanelli et al., 1998); vasoactive intestinal peptide receptor (VIP-R) in birds and mammals (Johnson and Tilly, 1988; Kawashima, 1995; El-Gehani et al., 1998; Bajo et al., 2000; Vaccari et al., 2006); NPY-R in mammals (Kopp et al., 1997); CRF-R in mammals (Heinrich et al., 1998; Waser et al., 2006), urocortin receptor in mammals (Florio et al., 2004) and kisspeptin receptor (GPR54) in mammals (Shahed and Young, 2009), supports this function. See Table 1 for further clarification.

In the same way that synthesis and actions of steroids in the brain or other, non-gonadal tissues are often overlooked (Schmidt et al., 2008), so are the synthesis and actions of gonadal neuropeptides. It is likely that the synthesis and actions of these hormones are often not taken into consideration in endocrine studies because they fall outside the classic endocrine axes (for example, the hypothalamo-pituitary-gonadal [HPG] axis). It is also sometimes harder to manipulate these systems in isolation within the gonads or brain than as intact components of the classic axes. Generally, neural or gonadal tissue needs to be cultured ex vivo in order to gain some understanding of the hormone of interest that they produce, which of course limits interpretation. Furthermore, although it is somewhat logical to assume that the brain is able to interpret environmental and physiological cues and regulate its own steroid production, it is harder to understand 
Table 1 | Presence of neuropeptides in the gonads of vertebrates. GnRH isoforms appear to be highly conserved across vertebrates, but there are large gaps in our knowledge of the evolution of other gonadal neuropeptides.

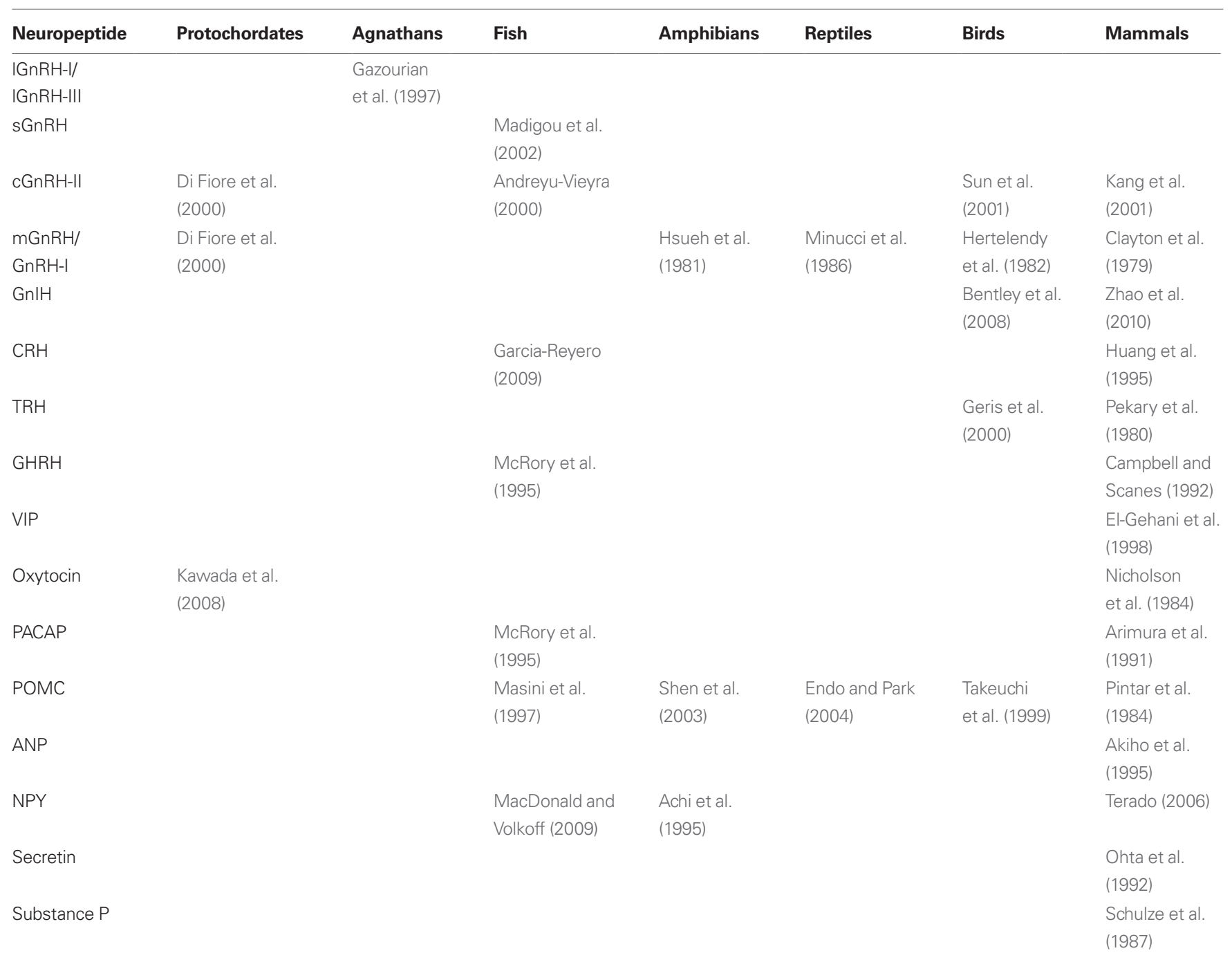

GnRH, Gonadotropin-releasing hormone; IGnRH, isoforms from lamprey; sGnRH, salmon; cGnRH-II, chicken; mGnRH/GnRH-I, mammals; GnIH, Gonadotropin inhibiting hormone; $\mathrm{CRH}$, Corticotropin releasing hormone, TRH, Thyrotropin releasing hormone; GHRH, Growth hormone releasing hormone; VIP, Vasoactive intestinal peptide; PACAP, Pituitary adenylate cyclase activating peptide; POMC, Pro-opiomelanocortin; ANP, Atrial natriuretic peptide; NPY, Neuropeptide Y.

how the gonads might respond to similar cues outside of the framework of the classic HPG axis. How, for example, does a gonad regulate its own GnRH production? Can a gonad respond to changes in day length, or social stimuli, or stress? How are these stimuli perceived?

Another consideration is that it might seem hard to understand why a gonadal neuropeptide system exists and how it evolved? The primary functions of gonads are to synthesize gonadal steroids and produce gametes, both of which appear to be exquisitely regulated and accomplished by the H-P components of the HPG axis. An additional, internal regulatory system in the gonad appears at first glance to be superfluous. It is possible that in early vertebrates, neural tissue containing neuropeptides and gonadal tissue were not as disparate as they are in modern vertebrates. It is thought that before the evolution of the vertebrate pituitary gland, $\mathrm{GnRH}$ neurons might have released $\mathrm{GnRH}$ directly into the bloodstream very close to the gonads and acted directly on the gonads (Powell et al., 1996). More evidence for this scenario comes from bivalve mollusks (Pazos and Mathieu, 1999). The vertebrate gonads may thus have retained the capability of at least responding to neuropeptides directly, but this does not enlighten us as to how the gonads have retained (or acquired) the capability of synthesizing neuropeptides such as GnRH. Additionally, all isoforms of $\mathrm{GnRH}$ are bioactive (affect DNA synthesis) in the molluskan gonad. The protochordate Ciona intestinalis, synthesizes two isoforms of $\mathrm{GnRH}$, mammalian $\mathrm{GnRH}(\mathrm{mGnRH})$ and chicken GnRH-II (cGnRH-II), in its gonads (Di Fiore et al., 2000). Ciona gonads cultured in vitro with both isoforms show an increase in sex steroid synthesis and release. The gonads of vertebrates may thus have retained the capability of producing and responding to neuropeptides directly. As well, in higher vertebrates, local control of the gonads may have been retained for rapid, transient 
responsiveness to environmental and physiological stimuli. It is less clear what the regulatory mechanisms governing the synthesis of these gonadal neuropeptides might be.

\section{NEUROPEPTIDES OF THE HPG AXIS IN THE GONADS}

Vertebrate gonadal tissues typically synthesize and contain receptors for several hormones that are classified as neuropeptides. For example, GnRH, a key hormone for vertebrate reproduction, and its receptor are present in the gonads of fish, amphibians, birds, reptile and mammals (Hsueh and Jones, 1981; Oikawa et al., 1990; Bahk et al., 1995; Grober et al., 1995; Di Matteo et al., 1996; Dong et al., 1996; Lin and Peter, 1996; Pati and Habibi, 1998; von Schalburg et al., 1999; Sun et al., 2001; Bogerd et al., 2002; Ikemoto and Park, 2007). Gonadal GnRH most likely plays an autocrine/paracrine function in the regulation of gonadal development and activity. For example, its action includes testicular steroidogenesis in rats and frogs (Hsueh et al., 1983; D'Antonio et al., 1992), spermatogenesis in fish (Andreu-Vieyra and Habibi, 2001; Andreu-Vieyra et al., 2005) and oocyte meiosis and follicular steroidogenesis in fish (Pati and Habibi, 2000). There is also variation in the expression of $\mathrm{GnRH}$ and GnRH-R across the estrus cycle and in a circadian manner in rats (Schirman-Hildesheim et al., 2005, 2006), although specific function has yet to be assigned to this variation.

Along with GnRH, this article will place emphasis on another neuropeptide involved in the HPG axis: GnIH. This neuropeptide was discovered 10 years ago in Japanese quail (Tsutsui et al., 2000), when it was isolated and found to inhibit pituitary luteinizing hormone (LH) release. It is now known that $\mathrm{GnIH}$ is a regulator of pituitary gonadotropin synthesis and release in birds and mammals (Tsutsui et al., 2000, 2007; Ciccone et al., 2004; Osugi et al., 2004; Bentley et al., 2006a; Kriegsfeld et al., 2006; Tsutsui and Ukena, 2006; Ubuka et al., 2006; Johnson et al., 2007; Clarke et al., 2009; Sari et al., 2009).

\section{GnRH IN THE GONADS}

Gonadotropin-releasing hormone was initially characterized as a hypothalamic neuroendocrine regulator of $\mathrm{LH}$ and follicle stimulating hormone (FSH) synthesis and release from the anterior pituitary gland (Ling et al., 1973; Schally et al., 1971). Evidence now exists that $\mathrm{GnRH}$ is also produced in, binds to and exerts a local action on the gonads. Several isoforms of GnRH (identified by both species letters and isoform numbers) and GnRH receptor are present in the gonads of vertebrates and will be discussed below. Many species possess multiple isoforms, including isoforms named as a result of their initial discovery in other species.

GnRH-I and GnRH type 1 receptor (GnRH-I R) are expressed in the mammalian gonads. This isoform is also known as mammalian GnRH (mGnRH). GnRH-I mRNA and GnRH-I R mRNA have been identified in granulosa and luteal cells of adult female rats (Oikawa et al., 1990; Whitelaw et al., 1995) and humans (Peng et al., 1994). In males, GnRH-I mRNA is present in Sertoli cells and germ cells of adult rats and humans, while the interstitial layer of the testis expresses GnRH-I R mRNA (Bahk et al., 1995). Gonadal GnRH is also expressed in fetal rats (Botté et al., 1998). In addition to GnRH-I, primate testes and ovaries express a second $\mathrm{GnRH}$ isoform, first characterized in chicken (cGnRH-II) and its receptor, GnRH type 2 receptor.
In addition to mammals, protochordates, fish, amphibians, reptiles and birds also express isoforms of GnRH and GnRH-R in their testes and ovaries (von Schalburg et al., 1999; Di Fiore et al., 2000; Sun et al., 2001; Canosa et al., 2002; Ikemoto and Park, 2007). See Table 1.

\section{EFFECTS OF GONADAL GnRH ARE ISOFORM-, SPECIES- AND SEX-DEPENDENT IN NON-MAMMALIAN VERTEBRATES}

The gonadal GnRH system has a diversity of functions in nonmammalian vertebrates. As mentioned earlier, the gonads of the protochordate Ciona intestinalis, synthesize both $\mathrm{mGnRH}$ and cGnRH-II (Di Fiore et al., 2000). Ciona gonads cultured in vitro with these isoforms show an increase in testosterone, progesterone and estradiol synthesis and release. A lamprey isoform of $\mathrm{GnRH}$ (lGnRH-III) significantly stimulates basal estradiol production and ovulation in the ovary and significantly increases estradiol and progesterone production in the testes of lampreys in vitro (Gazourian et al., 1997). In a later study, two isoforms of $1 \mathrm{GnRH}, \mathrm{GGnRH}-\mathrm{I}$ and -III, independently stimulated estradiol production by lamprey testis in vitro, with lGnRH-III being the more potent of the two $\mathrm{GnRH}$ isoforms used. In contrast to their earlier study, the authors conclude there is no direct effect of either form of $1 \mathrm{GnRH}$ on the ovary in this study, although the authors do state that "lamprey GnRH-III at $1000 \mathrm{ng} / \mathrm{ml}$ directly stimulated the ovaries incubated at $14^{\circ} \mathrm{C}(P<0.05)$ (data not shown)" (Gazourian et al., 2000). Taken together, it seems that the $\mathrm{GnRH}$ are capable of acting directly on male and female lamprey gonads to elicit steroid production.

The differential expression of $\mathrm{GnRH}$ isoforms and their cognate receptors in rainbow trout gonads indicates a role for these peptides in paracrine/autocrine regulation of gonadal function in this species. In the rainbow trout (Oncorhynchus mykiss), salmon GnRH ( $\mathrm{sGnRH}$ ) mRNA from whole testes increases as the spermatogenic cycle proceeds while chicken GnRH (cGnRH-II) mRNA decreases (Madigou et al., 2002). GnRH-R mRNA 1, which putatively codes for the receptor that binds $\mathrm{SGnRH}$, also increases in whole testes as spermatogenesis progresses (Madigou et al., 2002). Stage-specific expression indicates $\mathrm{s} \mathrm{GnRH}$ may be associated with spermatogenic development while cGnRH-II may hinder it. In whole ovaries, GnRH-R type 1 mRNA was undetectable in the same study, but sGnRH, cGnRH-II and GnRH-R type 2 mRNA were expressed from the beginning of vitellogenesis to post-ovulation (Madigou et al., 2002). Although the manner of this regulation remains unclear, when combined with functional evidence from goldfish- sGnRH and cGnRH-II inhibit gonadotropin-stimulated oocyte meiosis and follicular testosterone production (Pati and Habibi, 2000)- sGnRH and cGnRH-II are most probably involved in regulation of follicular hierarchy and/or maturation via inhibitory actions.

In toads (Bufo arenarum), mammalian GnRH (mGnRH or GnRH-I) inhibits basal and human chorionic gonadotropin (hCG)-stimulated testosterone release in the testes by decreasing the activity of cytochrome P450c17 (steroid 17 alphahydroxylase/17,20 lyase) (Hsueh et al., 1981). In leopard frogs, Rana pipiens, and bullfrogs, R. catesbeiana, no action of $1000 \mathrm{ng} /$ $\mathrm{ml} \mathrm{GnRH} \mathrm{was} \mathrm{observed} \mathrm{on} \mathrm{testosterone} \mathrm{or} \mathrm{progesterone} \mathrm{secre-}$ tion from mature follicles coincidently incubated with pituitary homogenate or with bullfrog LH (Hubbard and Licht, 1985). Which isoform of GnRH used here is not clear from this study, 
but we assume that it was $\mathrm{mGnRH}$ - this is important as different isoforms appear to have different effects. This may be one reason why some studies show inhibition while others show stimulation. In another, contrasting study on ovaries of frog (Rana esculenta), lizard (Podarcis sicula sicula) and fish (Torpedo ocellata and Gobius paganellus) indicated that the action of $\mathrm{GnRH}$ in the gonads may be species-dependent. In frogs, a GnRH agonist (GnRHa, HOE766) inhibited LH-induced progesterone release (Minucci et al., 1986) whereas in lizards, GnRHa stimulated progesterone production in preovulatory follicles. In both fish species studied no effects of GnRHa or ovine LH were seen. However, in a later study on goldfish (Carassius auratus), sGnRH and cGnRH-II increased testicular apoptosis, indicating a paracrine role for GnRH in the control of apoptosis. This effect of sGnRH and cGnRH-II on apoptosis was also observed in goldfish ovaries (Andreu-Vieyra and Habibi, 2000).

In cockerels (Gallus domesticus), both cGnRH-II and cGnRH-R are expressed in the testes in addition to the brain and although its regulatory role has not been tested, estrogen treatment appears to reduce the concentration of cGnRH-II in the testes (Sun et al., 2001). GnRH can directly alter steroid biosynthesis in chicken ovaries: LH- stimulated progesterone production is increased by $\mathrm{GnRH}$ in isolated granulosa cells of domestic chickens (Hertelendy et al., 1982). Differences in the stimulatory/inhibitory properties of GnRH in non-mammalian vertebrate gonads appear to be isoform-, species- and sex-dependent.

\section{EFFECTS OF GONADAL GnRH ON STEROID BIOSYNTHESIS IN THE MAMMALIAN TESTES}

GnRH immunoreactivity was first identified in the rat testis in 1981 (Paull et al., 1981) and rats have since been consistently used as a mammalian model for studies on the activity of gonadal GnRH-I. The GnRH-I R (GnRH type 1 receptor) in rat gonad is structurally identical to that in the pituitary (Moumni et al., 1994). Functionally, in immature rat testicular cells, GnRH decreases hCG/FSH- stimulated androstanediol and androsterone production, but not steroidogenic acute regulatory (StAR) protein and progesterone production (Hsueh et al., 1981). The short-term ( $4 \mathrm{~h}$ ) effect of the GnRH agonist LHRH ethylamide on Leydig cells is to stimulate steroidogenesis, but in contrast, 24-h stimulation with the agonist inhibits responsiveness to LH and hCG (Sharpe et al., 1982). In another study using adult rat primary testis culture, GnRH agonist decreased testosterone (T), androstenedione and 17a-OH progesterone (Hsueh et al., 1983). In yet another study, GnRH agonists inhibited LH-dependent steroid production in a dose-dependent fashion and abolished the acute testosterone rise in response to hCG. The expression of functional GnRH receptor during culture and its suppression by LH suggest that there is an interaction between pituitary gonadotropins and the gonadal GnRH system. It is likely that pituitary gonadotropins exert a tonic inhibitory effect upon testicular $\mathrm{GnRH}$ receptors. The presence of a functional GnRH receptor and inhibitory actions of GnRH agonists in cultured fetal and neonatal Leydig cells indicates that GnRH-related peptides can influence the actions of gonadotropins on the fetal Leydig cell population (Dufau and Knox, 1985).

\section{EFFECTS OF GONADAL GnRH ON STEROID BIOSYNTHESIS IN THE MAMMALIAN OVARY}

In female rats, GnRH-I is highly expressed and functional in the corpus luteum and in granulosa cells. Pharmacological levels of GnRH-I (0.5 uM) decrease basal luteal progesterone synthesis, but hCG (at concentrations greater than $10^{-13} \mathrm{M}$ ) is able to rescue this effect (Clayton et al., 1979). Cultured rat granulosa cells experience a significant reduction in estradiol (E2) and progesterone production stimulated by FSH in the presence of GnRH-I. No change in total mass occurs, apparently precluding an effect of GnRH in cell death (Hsueh and Erickson, 1979), although $\mathrm{GnRH}$ agonists have since been implicated in the promotion of ovarian apoptosis (Takekida et al., 2003). A later experiment by Hsueh et al. (1980) showed that GnRH reduces E2 production by preventing the FSH-induced 12 -fold increase in LH/hCG receptor expression in granulosa cells. If $\mathrm{GnRH}$ indirectly reduces E2 production via reduced $\mathrm{LH} / \mathrm{hCG}$ receptors in the ovary, ovarian androgen production should be directly reduced as well. Prepubertal female rat ovaries cultured with hCG, LH and leuprolide acetate, a GnRH agonist, show a concomitant decrease in both androsterone and $\mathrm{P} 450(\mathrm{C} 17)$ enzyme activity relative to ovaries treated with hCG/LH alone (Irusta et al., 2007). As we have already mentioned, GnRH-I inhibits P450(C17) in toad (Bufo arenarum) testes, resulting in decreased testosterone secretion (Canosa, 2002). Thus this property may be evolutionarily conserved. GnRH-I also appears to inhibit FSH-stimulated aromatase activity in addition to $\mathrm{P} 450$ (C17) inhibition in rat granulosa, but not Sertoli cells (Gore-Langton et al., 1981). The sex difference is likely due to the lack of GnRH-I R on male rat Sertoli cells. Again, there appears to be a sex and/or tissue difference, where $\mathrm{GnRH}$ is acting upstream of progesterone synthesis in the female corpus luteum but downstream of progesterone synthesis in male Leydig cells. Interestingly, the inhibitory effect of GnRH agonist on $17 \beta$-estradiol and progesterone secretion occurred in granulosa cells from large but not from small and medium follicles. The stimulatory effect of GnRH agonist on apoptosis was, however, uniform regardless of the stages of follicular growth (Takekida et al., 2003). Thus GnRH-I potentially exerts diverse actions on granulosa cells over the course of follicular growth. One is to downregulate granulosa cell proliferation in immature follicles as well as steroidogenesis in mature follicles, and the other is to upregulate apoptosis of granulosa cells, regardless of the stage of follicular growth.

Functionally, local GnRH action on estrogen synthesis may not be needed to regulate estrogen production in males, as estrogen has a much larger contribution to gametogenesis in females and would require tighter control in that sex. GnRH-I inhibits both androgen and consequently estrogen production in rat ovaries. In rat testes, GnRH-I primarily inhibits testosterone production. In both sexes, local GnRH modulates and primarily limits the major steroid supporting gamete maturation.

\section{GONADAL GnRH IN PRIMATES}

Humans and other primates express both mammalian GnRH (mGnRH/GnRH-I) and cGnRH-II and their cognate receptors (GnRH type 1 receptor/GnRH-I R and GnRH type 2 receptor/ 
GnRH-II R), in the testes and ovary (Bahk et al., 1995; Millar et al., 2001; Neill, 2002). Both receptors are members of the seven transmembrane family of $\mathrm{G}$ protein-coupled receptors and associated with Goq protein. GnRH-II R contains a c-terminal tail consistent with receptors able to internalize in response to high ligand concentration, while GnRH-I R lacks this tail and does not undergo receptor desensitization (Neill, 2002). Although rats have been used a pharmacological and medical model, the presence of cGnRH-II and its receptor have not been identified in rat gonads. In fact, the transcripts of cGnRH-II and GnRH-II $\mathrm{R}$ appear to be truncated in rat cDNA libraries generated from other tissues (Stewart et al., 2009). Thus it is hypothesized rats do not code for a functional GnRH-II R, and thus receptor densitization is a moot point for them. In human granulosa-luteal cells, GnRH-I inhibits progesterone production (as it does in rats), and this effect is completely reversed by the MEK1 inhibitor PD98059, indicating GnRH-I acts through the MAP kinase signaling pathway (Kang et al., 2000). cGnRH-II also inhibits basal and hCG-stimulated progesterone production and LH/FSH receptor expression (Kang et al., 2001). GnRH-I agonists have also been implicated in causing apoptosis in granulosa-luteal cells (Zhao et al., 2000). If gonadal GnRH decreases LH/FSH receptors, inhibits basal and hCG-stimulated progesterone production and increases apoptosis in the corpus luteum, it may serve a functional role in luteolysis. GnRH-I and cGnRH-II expression have been mapped across the luteal phase in primates and their comparative mRNA levels are consistent with this projection. GnRH-I mRNA expression is maximal at luteal regression, although GnRH-I R mRNA remains low throughout the luteal phase (Chakrabarti et al., 2008). An enhanced explanation of $\mathrm{GnRH}$ actions on the ovary during follicular development can be seen in Figure 1.

Less is known about the functional significance of GnRH-I and cGnRH-II and their receptors in the human and non-human primate testes. This is probably due to the greater availability of and higher occurrence of treatment on female reproductive tissues in fertility treatments. Although the bioactivity of systemically delivered $\mathrm{GnRH}$ antagonists has been studied for 25 years in primates in anticipation of their use as a male contraceptive (Weinbauer et al., 1984) and chemotherapy protectant (cetrorelix, Boekelheide et al., 2005), the testicular effects of GnRH-I and cGnRH-II are highly dependent upon reduced LH and FSH secretion from the pituitary and there have been no attempts to quantify direct effects of $\mathrm{GnRH}$ ex vivo. $1 \mathrm{GnRH}$ and $\mathrm{sGnRH}$ transcripts have not been identified in primate gonads.

\section{COMPARING THE ACTIONS OF HYPOTHALAMIC AND GONADAL GnRH: WHAT CAN WE INFER?}

Gonadal GnRH appears to act non-genomically, modifying enzyme activity through inositol phosphate breakdown via stimulation of its Goq receptor (Davis et al., 1986). This is also the mechanism used by hypothalamic GnRH on the pituitary for LH/FSH secretion. However differences between gonadotropes and granulosa/ luteal/interstitial cells cause the action of GnRH to be classified as "stimulatory" to reproduction in the pituitary and "inhibitory" to reproduction in the gonads.

\section{GnIH IN GONADS}

Gonadotropin-inhibitory hormone was so named for its discovery as an inhibitor of LH release from the pituitary of Japanese quail (Tsutsui et al., 2000). Later work has shown that GnIH inhibits both $\mathrm{LH}$ and FSH synthesis and secretion from the pituitary of birds and mammals (Kriegsfeld et al., 2006; Tsutsui et al., 2007). GnIH not only acts at the level of the pituitary gland to influence gonadotropin synthesis and release, but also within the brain of birds and mammals to inhibit GnRH neurons (see Bentley et al., 2006a, 2009; Tsutsui et al., 2009 for reviews). Therefore, there are several lines of evidence that GnIH can act directly on multiple components of the HPG axis.

Motivated by the direct action of $\mathrm{GnIH}$ on the other tissues of the HPG axis, we investigated the possibility that GnIH and/or its receptor are present in and act directly on the gonads of vertebrates. It is now clear that GnIH and GnIH-R are expressed in the gonads of birds and mammals, suggesting that GnIH acts directly elsewhere in the reproductive system. Further, our experimental evidence from pharmacological manipulations indicates that gonadal $\mathrm{GnIH}$ is responsive to cues from peripheral hormones and influences gonadal steroid release. These findings are important for us to understand the endocrine-behavior interactions when considering an animal's behavioral ecology. Further, a localized regulatory system in reproductive tissues is an important consideration/target for reproductive/contraceptive therapies.

\section{CONSERVATION OF GONADAL GnIH EXPRESSION AND ACTIONS}

A role for a local action of $\mathrm{GnIH}$ in vertebrate gonads was first hypothesized when systemic receptor fluorography revealed binding sites for $\mathrm{GnIH}$ on the thecal and granulosa layers of the ovary and within the interstitium and seminiferous tubules of the testes of white crowned sparrows (Zonotrichia leucophrys; Wingfield et al., 2004). Building upon this initial finding, gonadal GnIH was first characterized in European starlings and Japanese quail, species of two different orders of birds (Bentley et al., 2008). Transcripts for $\mathrm{GnIH}$ and GnIH-R were found in the quail and starling testes, quail epididymis, starling vas deferens and starling ovary and oviduct, indicating its potential as a paracrine/autocrine regulator within reproductive tissues. Immunohistochemistry and in situ hybridization further localized production sites of GnIH and GnIH-R to specific cell types involved in steroid biosynthesis and gamete maturation in the gonads. GnIH-immunoreactivity (GnIH-ir), indicating the presence of mature peptide, was detected in thecal and granulosa cells of starling ovaries and in the interstitium of the testes and psuedostratified columnar epithelium of the epididymus of quail testes (Bentley et al., 2008). In house sparrow testes, GnIH mRNA is present in the interstitium (McGuire and Bentley, 2010). GnIH-R mRNA was localized to the germ cells and interstitium of starling and house sparrow (Passer domesticus) testes (Bentley et al., 2008; McGuire and Bentley, 2010). In house sparrows, germ cell expression of GnIH-R was further characterized as secondary spermatocyte expression (McGuire and Bentley, 2010). In the ovary of chickens (Gallus domesticus), GnIH-R mRNA was detected in the thecal and granulosa layers by RT-PCR (Maddineni et al., 2008). GnIH mRNA has not been detected in chicken ovary (Maddineni et al., 2008), although sequencing of PCR products confirms the presence of transcripts for $\mathrm{GnIH}$ in the 
ovaries of the other bird species studied (McGuire and Bentley, 2010; McGuire et al., 2010). It is possible these birds carry an ovarian transcript not detectable by our current methods.

The sites of GnIH-R synthesis across birds are consistent with fluorescent $\mathrm{GnIH}$ binding observed in the first white crowned sparrow study. Thus GnIH-R transcript detection is most likely associated with functional receptors and appears conserved across passeriform and galliform birds.

Expression of GnIH mRNA and presence of $\mathrm{GnIH}$ peptide in steroid biosynthetic cells of the ovary and the testes, coupled with the presence of its Gai protein-coupled receptor there, provide the potential for this system to act in a paracrine/autocrine fashion to regulate steroid biosynthesis. As well, these findings indicate gonadal GnIH may be an important target for steroid production therapies. Furthermore, the expression of these components on germ cells indicates the gonadal GnIH system may be an important consideration in the development of gamete maturation therapies.

The mammalian ortholog of GnIH, RFRP, and its receptor are also present in the gonads of mammals. Syrian hamster spermatocytes and round to early elongated spermatids are immunoreactive for RFRP and its putative rodent receptors, GPR-147 and GPR-74 (Zhao et al., 2010). The two receptors are differentially present across the spermatogenic cycle; GPR 147 is present at all stages, while GPR-74 immunoreactivity is observable in late elongated spermatids only, indicating their expression may be stage-regulated. The sequential expression of RFRP and GPR-74 across different spermatogenic stages would allow a role for RFRP in the differentiation of germ cells in the testes.

\section{GONADAL GnIH IN PRIMATES}

The sperm development patterns of rodents and primates are quite similar (Clermont, 1972). Thus data garnered from the expression patterns of RFRP and GPR-74 across the spermatogenesic cycle of hamsters provide an excellent model for studies of sperm development issues in humans. Although the gonadal expression of RFRP and OT7T022, its human cognate receptor, have not been studied in humans, RFRP and OT7T022 are expressed in the human hypothalamus (Ubuka et al., 2009).

RFRP is not observed in the interstitium of Syrian hamsters. However, RFRP-ir and mRNA are present in the steroid biosynthetic cells as well as the germ cells of the rhesus macaque (Macaca

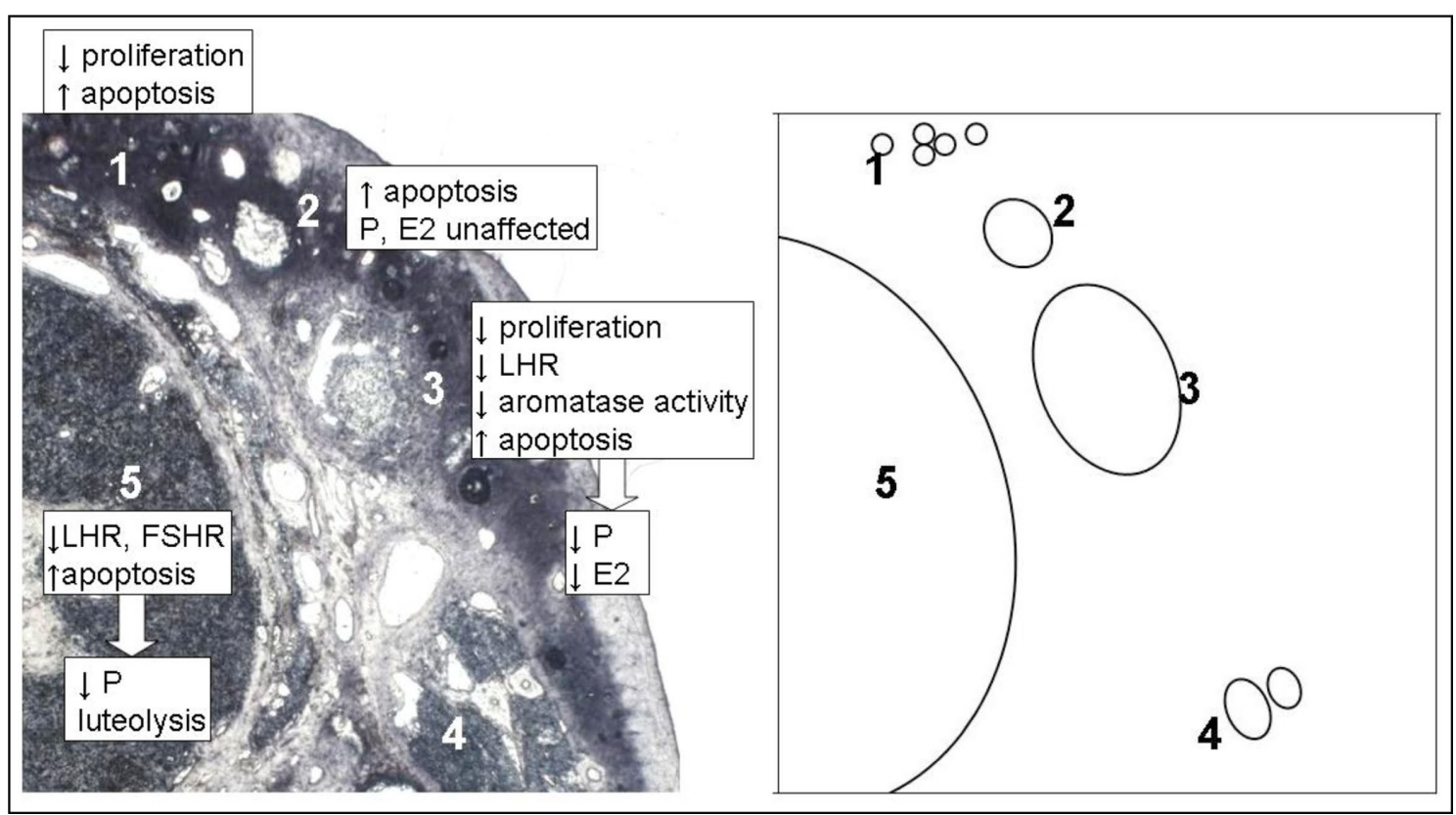

FIGURE 1 |Theoretical construct of local gonadotropin-releasing hormone ( $\mathrm{GnRH}$ ) action on follicular development in the mammalian ovary, based on experimental evidence. $\mathrm{GnRH}$ and $\mathrm{GnRH}$ receptor ( $\mathrm{GnRH}-\mathrm{R})$ are expressed on granulosa cells at all stages of follicular development and on granulosa-luteal cells of corpora lutea. Prehierarchical follicles (1) are not stimulated by Follicle stimulating hormone (FSH) and gonadal $\mathrm{GnRH}$ reduces granulosa cell numbers by reducing proliferation and increasing apoptosis in these follicles (Takekida et al., 2003). As follicles gain the ability to respond to $\mathrm{FSH}$, they overcome this inhibition and grow into small/medium hierarchical follicles (2). GnRH increases apoptosis of granulosa cells in these follicles, but this does not cause a significant reduction in the secretion of already low levels of estradiol (E2) and progesterone (P) (Takekida et al., 2003). FSH, P and E2 enhance the growth of these follicles into large hierarchical follicles (3). $\mathrm{GnRH}$ reduces granulosa cell proliferation, aromatase activity (Gore-Langton et al., 1981) and luteinizing hormone receptor (LH-R) expression (Hsueh et al., 1980) while continuing to increase granulosa cell apoptosis (Takekida et al., 2003). All of these factors contribute to a significant decrease in the secretion of E2 and P from these follicles (Hsueh et al., 1980; Takekida et al., 2003). The reduction in LH-R also makes the follicle less able to respond to the LH surge with ovulation. If large hierarchical follicles are not able to overcome this inhibition, their growth will cease and they would become atretic (4). If a large hierarchical follicle does overcome inhibition by $\mathrm{GnRH}$ it can become the corpus luteum (5) post-ovulation. GnRH decreases $\mathrm{LH}-\mathrm{R}$ and FSH-R expression in, reduces secretion of progesterone from and increases apoptosis of granulosa-luteal cells (Kang et al., 2000, 2001; Zhao et al., 2000). The highest expression of $\mathrm{GnRH}$ and $\mathrm{GnRH}-\mathrm{R}$ occurs at the end of the luteal phase (Chakrabarti et al., 2008), indicating $\mathrm{GnRH}$ may be a contributing factor to luteolysis. The diagram on the right is a representation of the photomicrograph on left, showing the relative location of each follicular stage for clarity. 


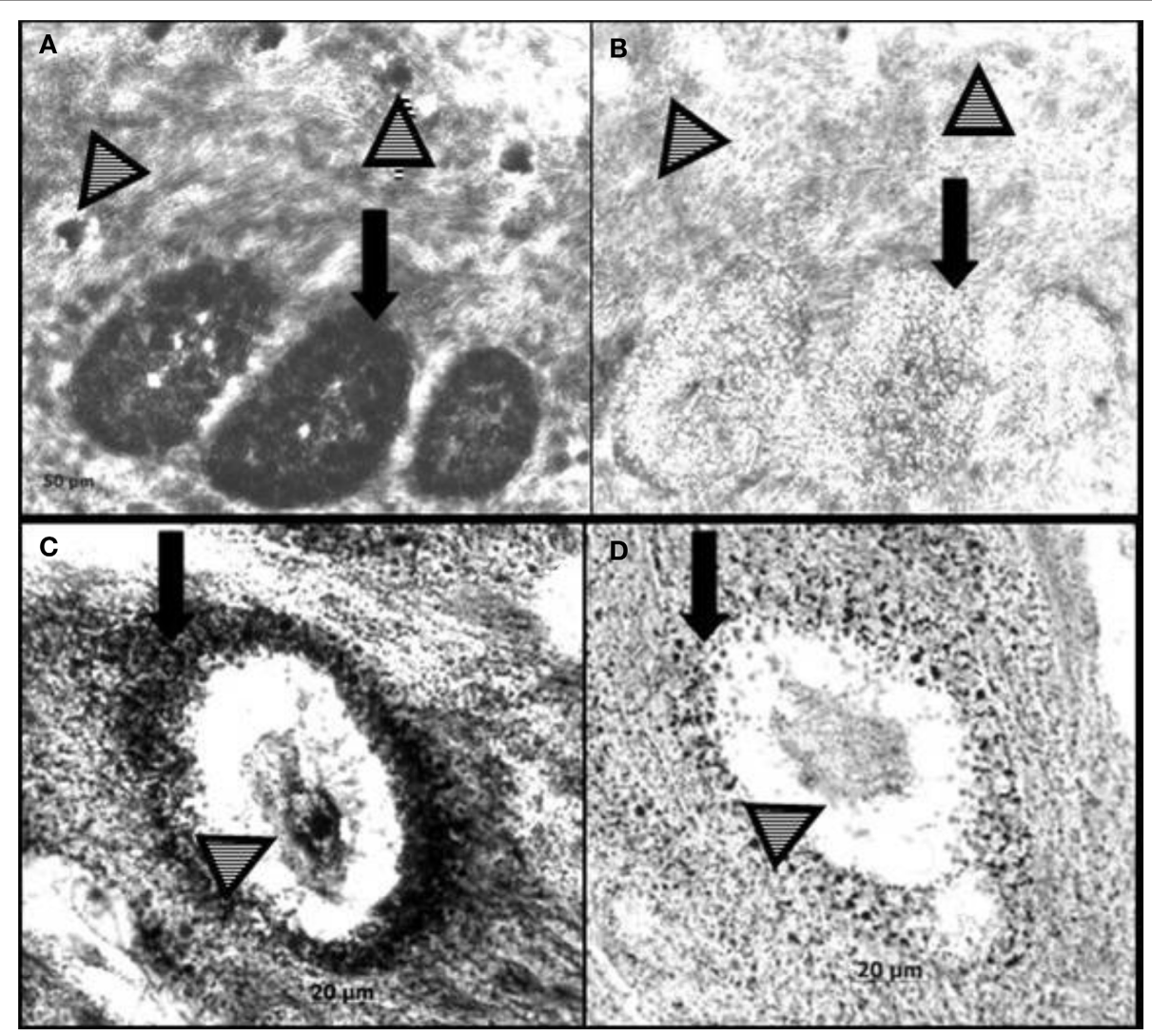

FIGURE 2 | In situ hybridization for RF-amide related peptide (RFRP) and its receptor (OT7T022) in rhesus macaque (Macaca mulatta) ovary. RFRP antisense probe labels mRNA in granulosa cells and oocytes (A). An adjacent section incubated with RFRP sense probe (control) is shown in (B). OT7T022 antisense probe labels mRNA in granulosa cells and oocytes (C). An adjacent section incubated with OT7T022 sense probe (control) is shown in (D). Black arrows, granulosa cells. Striped arrowheads, oocytes. mulatta) testes. mRNA for OT7T022, the putative macaque RFRP receptor, is also expressed there (Figure 2). In situ hybridization reveals the presence of transcripts for RFRP in Leydig cells, spermatogonia, and spermatocytes. The location of OT7T022 mRNA on spermatogonia, spermatocytes and Sertoli cells and Leydig cells (Figure 3). RFRP and OT7T022 are also expressed on rhesus macaque ovarian tissue. RFRP-ir and mRNA and OT7T022 mRNA are present on granulosa cells and oocytes of preantral follicles (Figure 2). Non-hierarchical follicles and corpora lutea were not tested. Cell types were identified based on rhesus macaque gonadal morphology (Gougeon, 1996; Boekelheide et al., 2005), and with concurrent sections labeled with hematoxylin and eosin stain (data not shown). RFRP thus has the potential to act as a regulator of steroid biosynthetic cells and gametes in rhesus macaque testes and ovaries.

The expression pattern of RFRP and OT7T022 in primate gonads appears to be more closely related to that observed in seasonallybreeding songbirds than to hamsters (Table 2). Like house sparrows and hamsters, rhesus macaques undergo seasonal cycles of gonadal growth and regression characterized by significant changes in sex steroids and gametogenesis (Riesen et al., 1971; Gupta et al., 2000; Bansode et al., 2003), in which the gonadal GnIH system may play a regulatory role. It is not at present clear why hamsters differ from songbirds and rhesus macaques in the expression patterns of $\mathrm{GnIH}$ and its receptor.

Although human reproductive cycles are not thought to be regulated by photoperiod or rain, they nonetheless retain the ability to modulate their reproductive output during times of food restriction and stress (Vigersky et al., 1977; Vermeulen, 1993; Ferin, 1999). The conserved nature of gonadal neuropeptide systems makes it likely that this mechanism allowing for enhanced reproductive responsiveness is most likely conserved in humans as well.

\section{COMPARING THE ACTIONS OF HYPOTHALAMIC AND GONADAL GnIH: WHAT CAN WE INFER?}

Although the expression sites/pattern of $\mathrm{GnIH}$ and its receptor are suggestive of a role in steroid synthesis and gamete maturation, a general inhibitory action for the peptide cannot be inferred simply based on direct inhibition of GnRH (Ducret et al., 2009) and LH/ FSH (Tsutsui et al., 2000) by its more characterized counterpart in the hypothalamus. However, GnIH-R has the same sequence, is recognized by the same antibodies and mRNA probes and binds fluorescently-labeled GnIH identically to pituitary GnIH-R (Wingfield et al., 2004; Bentley et al., 2008; Maddineni et al., 2008; McGuire 


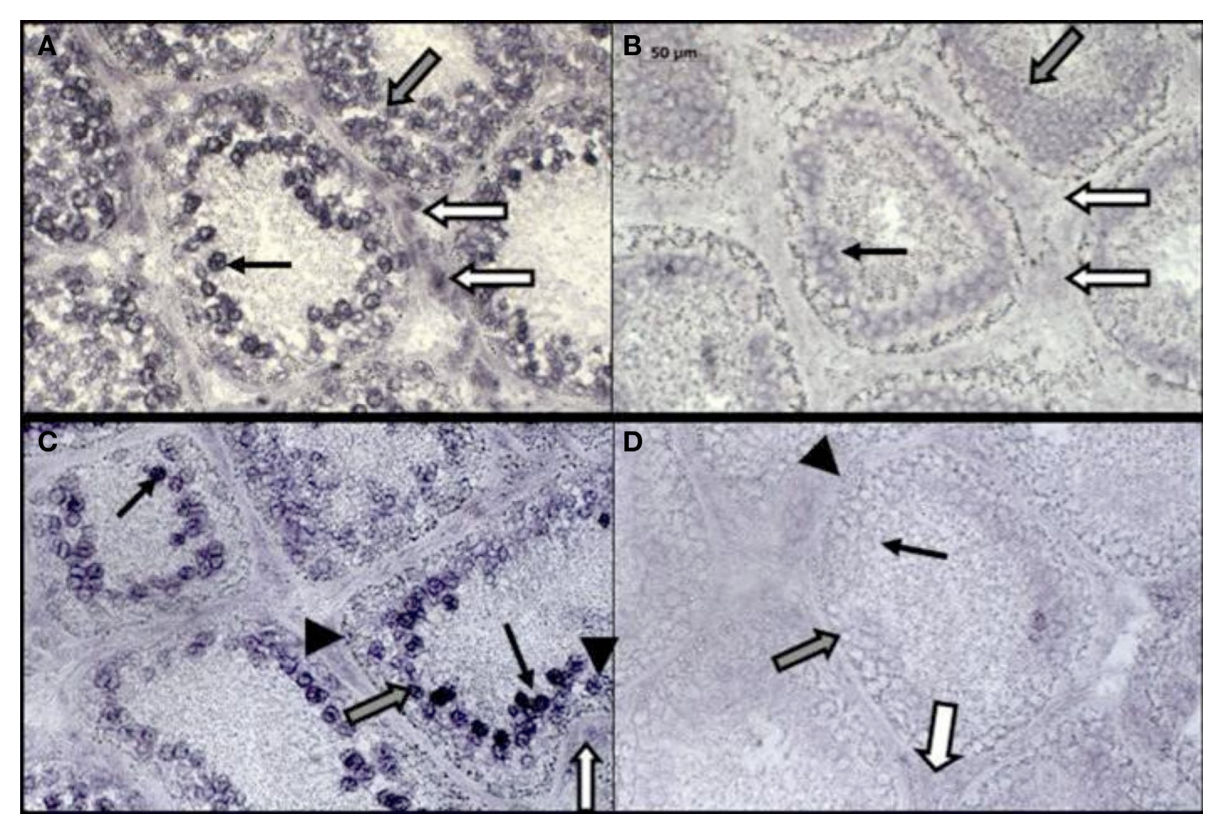

FIGURE 3 | In situ hybridization for RF-amide related peptide (RFRP) and its receptor (ОT7T022) in rhesus macaque (Macaca mulatta) testis. RFRP antisense probe labels mRNA in Leydig cells, spermatogonia and spermatocytes (A). An adjacent section incubated with RFRP sense probe (control) is shown in (B). OT7T022 antisense probe labels mRNA in Leydig cells, Sertoli cells, spermatogonia and spermatocytes (C). An adjacent section incubated with OT7T022 sense probe (control) is shown in (D). White arrows, Leydig cells. Gray arrows, spermatogonia. Black arrows, spermatocytes. Black arrowheads, Sertoli cells. All figures to scale, scale bar $=50 \mu \mathrm{m}$

Table 2 | Summary of RFRP and OT7T022 mRNA and peptide localization in rhesus macaques.

\begin{tabular}{|c|c|c|c|c|c|c|}
\hline Cell type & Macaque RFRP & Macaque ОT7T022 & Avian GnIH & Avian GnlH-R & Rodent RFRP & Rodent GPR74 \\
\hline Spermatocytes & $\checkmark$ & $\checkmark$ & $\checkmark$ & $\checkmark$ & $\checkmark$ & \\
\hline Spermatozoa & - & - & - & - & $\checkmark$ & $\checkmark$ \\
\hline Sertoli cells & - & $\checkmark$ & - & - & - & - \\
\hline Interstitium & $\checkmark$ & $\checkmark$ & $\checkmark$ & $\checkmark$ & - & - \\
\hline Oocytes & $\checkmark$ & $\checkmark$ & - & - & & \\
\hline Granulosa cells & $\checkmark$ & $\checkmark$ & $\checkmark$ & $\checkmark$ & & \\
\hline Thecal cells & - & - & $\checkmark$ & $\checkmark$ & & \\
\hline
\end{tabular}

Avian GnIH mRNA and peptide and GnIH-R mRNA and binding sites characterized in European starlings (Sturnus vulgaris, Bentley et al., 2008), house sparrows (Passer domesticus, McGuire and Bentley, 2010), Japanese quail (Coturnix japonica, Bentley et al., 2008) and domestic chicken (Gallus gallus, Maddineni et al., 2008). Rodent RFRP and GPR74 peptides characterized in hamster (Mesocricetus auratus, Zhao et al., 2010). Checkmarks indicate presence in the cell type, dashes denote lack of mRNA, peptide or binding sites and blank spaces indicate lack of evidence.

et al., 2010). Yin et al. (2005) identified GnIH-R in quail pituitary as a member of the GPCR family coupled to Goi/o. Thus agonist binding of this receptor causes inhibition of adenylate cyclase. Hinuma et al. (2000) showed that agonist binding of rat RFRP receptor reduced the forskolin-induced cAMP response in transfected Chinese hamster ovary $(\mathrm{CHO})$ cells. Inhibition of forskolin- stimulated adenylate cyclase and consequent decreased cAMP accumulation was later confirmed in chicken pituitary (Shimizu and Bédécarrats, 2010).
Thus it is likely that binding of GnIH/RFRP to it receptor in the gonads also reduces cAMP accumulation and inhibits transcription of proteins with cAMP responsive elements.

\section{GONADAL GnIH AND TESTOSTERONE SYNTHESIS}

GnIH has the potential to, but does it actually directly affect testosterone synthesis in the testes? Systemic (intraperitoneal) administration of $\mathrm{GnIH}$ to male quail reduced plasma testosterone and caused apop- 
tosis in testicular germ cells (Ubuka et al., 2006). These researchers concluded that the effects were caused by a reduction in LH secretion from the pituitary. However, the administration route for $\mathrm{GnIH}$ (i.p. via osmotic pumps) did not prevent its action elsewhere in the HPG axis. GnIH could be acting both to decrease LH secretion from the pituitary (indirectly effecting testosterone secretion) and by binding its receptor in the gonads and directly decreasing testosterone. The presence of $\mathrm{GnIH}$ receptor was later identified in quail testes (Bentley et al., 2008), specifically on germ cells and in the interstitium. A parsimonious explanation of these data is that significant apoptosis in germ cells of $\mathrm{GnIH}$-treated birds versus saline control birds resulted from lack of testosterone support (testosterone reduced by lower LH stimulation and higher direct GnIH inhibition) and/or direct action of GnIH on germ cells. Additionally, the observed reduction in testosterone was the result of both reduced gonadotropin support and direct action of $\mathrm{GnIH}$ in the interstitium. New evidence from house sparrows suggests that $\mathrm{GnIH}$ can directly reduce testosterone secretion from the testes. 1 and $10 \mathrm{uM}$ doses of $\mathrm{GnIH}$ significantly reduced the amount of testosterone secreted from LH/FSH- stimulated house sparrow testes cultured in vitro (McGuire and Bentley, 2010). GnIH does not have a significant effect on basal testosterone synthesis, suggesting the gonadal $\mathrm{GnIH}$ system acts to regulate high levels of testosterone secretion and would have the greatest regulatory capability in post-pubertal males. Thus GnIH can reduce testosterone via two mechanisms: GnIH reduces LH/FSH secretion from the pituitary, decreasing stimulation to produce testosterone and $\mathrm{GnIH}$ inhibits testosterone secretion in the testes directly, in the presence of LH/ FSH stimulation.

Why would such a system be necessary? Why not constantly support tonically high levels of testosterone, the highest sperm production levels and the highest frequency of reproductive displays possible? High testosterone levels are associated with a number of pathologies in vertebrates, including prostate cancer and immunocompromise (Gann et al., 1996; Roberts et al., 2007). The brain already controls a mechanism whereby high levels of gonadal steroids limit further secretion of the hormones that stimulate their synthesis, but this process requires a lengthy and time-consuming feedback loop. Fine-tuning of testosterone secretion on-site is highly adaptive in species with temporally or socially constrained breeding - especially if that system (in this case the gonad) is able to respond directly to environmental cues.

\section{GONADAL GnIH AND ESTRADIOL SYNTHESIS}

Based on its distribution, GnIH has the potential to, but does it actually directly affect estradiol synthesis in the ovary? The viability of granulosa cells from chicken ovaries was significantly reduced when cultured with GnIH alone but not when FSH was present in the culture medium (Maddineni et al., 2008). Dispersion culture of whole European starling ovary reveals that $\mathrm{GnIH}$ reduces basal, but not LH/FSH-stimulated estradiol production (McGuire et al., 2010). Taken together, these data suggest that $\mathrm{GnIH}$ affects basal estradiol synthesis in the ovary by reducing viability of granulosa cells and this effect is rescued by FSH.

The expression pattern of GnIH-R in ovaries is consistent with the observed reduction of basal, but not gonadotropin-stimulated estradiol production. Sexually immature chickens express significantly more ovarian GnIH-R mRNA compared to sexually mature chicken ovaries (Maddineni et al., 2008). Among mature hens, GnIH-R mRNA is significantly decreased by estradiol and progesterone alone and in combination (Maddineni et al., 2008). Like the differential expression of RFRP and GPR-74 in Syrian hamster testes, ovarian GnIH-R/OT7T022 has hierarchical expression in the ovary. GnIH-R mRNA is expressed on both prehierarchical and preovulatory follicles in hens (Maddineni et al., 2008) and on preantral follicles in macaque (Figure 2). There is no difference in the relative levels of GnIH-R mRNA on granulosa cells between the two stages of hen follicles, although prehierarchical follicles express significantly more GnIH-R mRNA on their thecal cells than do preovulatory follicles. We therefore propose this scenario: in the absence of FSH stimulation, GnIH reduces granulosa cell viability in follicles (which would all be prehierarchical in the absence of FSH), reducing estradiol secretion and inhibiting their maturation. As follicles mature, expression of GnIH-R mRNA on the theca is reduced, allowing them to respond to an LH surge with ovulation and progesterone production. Postovulation, granulosa cell numbers of hierarchical follicles that did not ovulate are reduced in the absence of FSH and presence of unchanged levels of GnIH-R, causing follicular atresia. Overall, evidence suggests ovarian $\mathrm{GnIH}$ has the greatest regulatory capability in prepubertal hens and in the prehierarchical or atretic follicles of sexually mature hens, in contrast to the effects seen in males.

The mechanism and timing of regulation by gonadal GnIH may be very different in male and female gonads. In males, GnIH acts as a regulator of stimulated testosterone production and possibly gamete maturation. In females, $\mathrm{GnIH}$ has a role in the prevention of follicle maturation and ovulation. As with gonadal $\mathrm{GnRH}$, there appear to be sex differences in the actions of gonadal GnIH.

\section{GONADAL GnIH AND THE ORGANISM'S ENVIRONMENT}

Is the gonadal GnIH system able to directly respond to environmental cues? New evidence from starling testes and ovaries indicates that LH/FSH-stimulated testosterone and estradiol levels are directly reduced by cortisol and melatonin (McGuire et al., 2010, unpublished observation). Cultures treated with cortisol and melatonin also show higher levels of GnIH mRNA relative to LH/FSHstimulated cells (McGuire et al., 2010, unpublished observation). Thus it is likely that the gonads directly respond to stress and an endocrine proxy of day length. Although changes in seasonal day length are not cause for concern in most humans, these results point toward significant effects in shift workers, pilots/flight attendants and those who self-medicate with over-the-counter melatonin. The stress-related hormone cortisol may act on $\mathrm{GnIH}$ and other factors to reduce follicle maturation. This might have evolved as an adaptive process, allowing an organism to wait to breed until conditions are more favorable - but it may be one mechanism in stress-induced infertility. Additionally, corticosteroid pharmaceuticals may have biologically significant effects on estradiol production and ovarian function. Recently, we found that female rats express glucocorticoid receptor (GR) transcripts in their ovaries, even when not stressed (McGuire et al., unpublished observation). However, they still significantly increase GR mRNA in the ovary in response to chronic, but not acute stress. This indicates that the ovaries are highly responsive to levels of the stress hormone cortisol in the plasma and that they may become increasingly responsive to stressful events with repeated exposure. 


\section{CURRENT PHARMACOLOGY OF GONADAL GnRH AND GnIH}

Why do transient increases in $\mathrm{GnIH}$ or GnRH and decreases in testosterone and estradiol matter? Repeated events which stimulate or inhibit this system over time may lead to decreased fertility or increased cancer risk. Can pharmacological treatments manipulate this ratio favorably? Will pharmacological treatments inadvertently manipulate this ratio unfavorably? Should gonadal GnIH and GnRH be considered in the development of new contraceptives/ fertility treatments/cancer therapies?

\section{GnRH AND OVARIAN CANCER LINES}

The stimulatory potential of GnRH-I has already made it a target of oncology. For example, GnRH antagonists and cytotoxic GnRH analogues have been used to inhibit the pituitary and retard growth of ovarian and prostate cancers (Schally, 1999). However, the assumed function of these systemic treatments precludes the ability of $\mathrm{GnRH}$ to act directly on the ovary. In the case of GnRH antagonists, the therapy may in fact further proliferation within the gonad and reduce programmed cell death. The direct inhibitory capability of $\mathrm{GnRH}$ analogs on granulosa cells of the ovaries of a variety of species indicates that there is the potential for some therapies to be more localized: direct application of $\mathrm{GnRH}$ agonists or cytotoxic $\mathrm{GnRH}$ at the gonadal tumor site to reduce proliferation and cause apoptosis locally, while sparing the rest of the ovary. Further research is needed to determine GnRH receptor expression in cancerous cells. GnRH-II has been less well studied than GnRH-I.. However, GnRH-II and its receptor are expressed in human ovarian cancer cell lines and native GnRH-II dose- and time-dependently reduces proliferation in those cancer cells (Gründker et al., 2002). The observed effect is significantly more potent than the anti-proliferative ability of GnRH-I. As well, these researchers showed GnRH-II was able to reduce proliferation in another ovarian cancer cell line, SK-OV-3, which is not responsive to GnRH-I. Development of GnRH-II analogues will further this line of research.

\section{GnIH ANTAGONIST}

RF9 is a recently reported agent that blocks opiod-induced hyperalgesia by antagonizing the NPFF receptor. RF9 also antagonizes the closely related RFRP receptor, preventing regulation of the HPG axis by RFRP. A pharmacological dose of RF9, delivered in a single bolus ICV injection, causes robust secretion of LH and FSH in diestrus- 1 and estrus female rats (Pineda et al., 2010). These profiles are stronger and longer lasting than those induced by kisspeptin administered ICV. In male rats, RF9 causes a robust, but transient increase in LH secretion. Thus, pharmacological doses of this chronic pain treatment antagonize RFRP receptor and remove its inhibitory action from LH/FSH secretion. The researchers point

\section{REFERENCES}

Achi, M. V., Figueroa, J. M., González Nicolini, V., Villar, M. J., and Tramezzani, J. H. (1995). NPY- and CGRP-like immunoreactive nerve fibers in the testis and mesorchium of the toad (Bufo arenarum). Cell Tissue Res. 281, 375-378.

Akiho, H., Chijiiwa, Y., Okabe, H., Harada, N., and Nawata, H. (1995).
Interaction between atrial natriuretic peptide and vasoactive intestinal peptide in guinea pig cecal smooth muscle. Gastroenterology 109, 1105-1112.

Andreu-Vieyra,C.V.,Buret,A.G., and Habibi, H. R. (2005). Gonadotropin-releasing hormone induction of apoptosis in the testes of goldfish (Carassius auratus). Endocrinology 146, 1588-1596.

out that the downstream activation of the HPG axis, as a side effect of using RF9 in chronic pain management, should be carefully considered. Given the local action of GnIH on the gonads themselves, direct action of RF9 in the testes and ovaries may be highly consequential as well. RF9 action on the gonads could cause overproduction of sperm, benign prostatic hyperplasia, ovarian cysts or high synthesis of testosterone and estradiol, which may predispose the patient to increased risk of breast, prostate or uterine cancer over time. Conversely, it may be a positive therapy in infertile patients.

\section{CONCLUDING REMARKS}

It is clear from the differences in action of GnRH, and sites of synthesis and receptor binding of GnIH in different study organisms even within the same vertebrate class that it would be unwise to create any sweeping generalizations about the gonadal actions of these peptides. The take-home message is that despite our knowledge of the existence of many gonadal neuroeptide systems (see Table 1) we still only have a vague understanding of how they operate and are regulated. It is also clear that we cannot assume that a gonadal neuropeptide will operate in a similar manner to its hypothalamic counterpart. Given that GnRH is the most well-studied gonadal neuropeptide our knowledge of it is rather poor. However, study of gonadal GnRH has provided us with some ideas as to how the HPG axis might have evolved from a common ancestor, and some important insights as to its gonadal actions. Table 1 indicates the large gaps in our knowledge of the existence of gonadal neuropeptides in different vertebrate classes; further comparative studies can only be beneficial in terms of creating a framework of knowledge upon which we can build and create novel therapeutic drugs, deepen our understanding of the evolution of the vertebrate reproductive system, and provide us with clues as to how the gonadal neuropeptides have adapted to the ecology of different vertebrates. In part, the naming of these peptides as neuropeptides creates immediate bias in terms of our consideration that they might exist in the gonads. Further, the functional names given to the gonadal counterparts of the neuropeptides in question might also bias us as to our consideration of their actions -with possible detriment to science and medicine. We feel that the time is ripe for further exploration of the gonads in terms of discovering new gonadal neuropeptides in different vertebrate classes as well as elucidating the actions of those already known to exist.

\section{ACKNOWLEDGMENTS}

Funded by NSF IOS 0641188 and 0920753 to George E. Bentley and National Science Foundation Graduate Research Fellowship to Nicolette L. McGuire.

Andreu-Vieyra, C. V, Habibi, H. R. (2000) Factors controlling ovarian apoptosis. Can. J. Physiol. Pharmacol. 78, 1003-1012.

Andreu-Vieyra,, C. V., and Habibi, H. R. (2001). Effects of salmon GnRH and chicken GnRH-II on testicular apoptosis in goldfish (Carassius auratus). Comp. Biochem. Physiol. B, Biochem. Mol. Biol. 129, 483-487.
Arimura, A., Somogyvári-Vigh, A., Miyata, A., Mizuno, K., Coy, D. H., and Kitada, C. (1991). Tissue distribution of PACAP as determined by RIA: highly abundant in the rat brain and testes. Endocrinology 129, 2787-2789.

Bahk, J. Y., Hyun, J. S., Chung, S. H., Lee, H., Kim, M. O., Lee, B.H., and Choi, W. S. (1995). Stage specific identification of the expression of GnRH mRNA and 
localization of the $\mathrm{GnRH}$ receptor in mature rat and adult human testis. J. Urol. 154, 1958-1961.

Bajo, A. M, Juarranz, M. G., Valenzuela, P., Martínez, P., Prieto, J. C., and Guijarro, L. G. (2000). Expression of vasoactive intestinal peptide (VIP) receptors in human uterus. Peptides 21, 1383-1388.

Bansode, F. W., Chowdhury, S. R., and Dhar, J.D. (2003). Seasonal changes in the seminiferous epithelium of rhesus and bonnet monkeys.J. Med. Primatol. 32, 170-177.

Bentley, G. E., Kriegsfeld, L. J., Osugi, T., Ukena, K., O'Brien, S., Perfito, N., Moore, I. T., Tsutsui, K., and Wingfield, J. C. (2006a). Interactions of gonadotropin-releasing hormone $(\mathrm{GnRH})$ and gonadotropin-inhibitory hormone $(\mathrm{GnIH})$ in birds and mammals. J. Exp. Zoolog. Part A Comp. Exp. Biol. 305, 807-814.

Bentley, G. E., Jensen, J. P., Kaur, G. J., Wacker, D. W., Tsutsui, K., and Wingfield, J. C. (2006b). Rapid inhibition of female sexual behavior by gonadotropin-inhibitory hormone (GnIH). Horm. Behav. 49, 550-555.

Bentley, G. E., Ubuka, T., McGuire, N. L., Calisi, R. M., Perfito, N., Kriegsfeld, L. J., WIngfield, J. C., and Tsutsui, K. (2009). GnIH: a multifunctional neuropeptide. J. Neuroendocrinol. 21, 276-281.

Bentley, G. E., Ubuka, T., McGuire, N. L., Chowdhury, V. S., Morita,, Y., Yano T., Hasunuma, I., Binns, M., Wingfield, J.C., and Tsutsui, K. (2008). Gonadotropin-inhibitory hormone and its receptor in the avian reproductive system. Gen. Comp. Endocrinol. 156, 34-43.

Boekelheide, K., Schoenfeld, H. A., Hall, S. J., Weng, C. C., Shetty, G., Leith, J., Harper, J., Sigman, M., Hess, D. L., and Meistrich, M.L. (2005). Gonadotropinreleasing hormone antagonist (Cetrorelix) therapy fails to protect nonhuman primates (Macacaarctoides) from radiation-induced spermatogenic failure. J. Androl. 26, 222-234.

Bogerd, J., Diepenbroek, W. B., Hund, E., van Oosterhout, F., Teves, A. C., Leurs, R., and Blomenröhr, M. (2002). Two gonadotropin-releasing hormone receptors in the African catfish: no differences in ligand selectivity, but differences in tissue distribution. Endocrinology 143, 4673-4682.

Botté, M. C., Chamagne, A. M., Carré, M. C., Counis, R., and Kottler, M. L. (1998). Fetal expression of GnRH and $\mathrm{GnRH}$ receptor genes in rat testis and ovary. J. Endocrinol. 159, 179-189.

Campbell, R. M., and Scanes, C. G. (1992). Evolution of the growth hormonereleasing factor (GRF) family of peptides. Growth Regul. 2, 175-191.
Castellano, J. M., Gaytan, M., Roa, J., Vigo, E., Navarro, V.M., Bellido, C., Dieguez, C., Aguilar, E, Sánchez-Criado, J. E., Pellicer, A., Pinilla, L., Gaytan, F., and Tena-Sempere, M. (2006). Expression of KiSS-1 in rat ovary: putative local regulator of ovulation? Endocrinology $147,4852-4862$.

Chakrabarti, N., Subbarao, T., Sengupta, A., Xu, F., Stouffer, R. L., and Sridaran, R. (2008). Expression of mRNA and proteins for GnRH I and II and their receptors in primate corpus luteum during menstrual cycle. Mol. Reprod. Dev. 75, 1567-1577.

Ciccone, N. A., Dunn, I. C., Boswell, T., Tsutsui, K., Ubuka, T., Ukena, K., and Sharp, P. J. (2004). Gonadotrophin inhibitory hormone depresses gonadotrophin alpha and follicle-stimulating hormone beta subunit expression in the pituitary of the domestic chicken. J. Neuroendocrinol. 16, 999-1006.

Clarke, I. J., Qi, Y., Puspita Sari, I., and Smith, J. T. (2009). Evidence that RF-amide related peptides are inhibitors of reproduction in mammals. Front. Neuroendocrinol. 30, 371-378.

Clayton, R. N., Harwood, J. P., and Catt, K. J. (1979). Gonadotropin-releasing hormone analogue binds to luteal cells and inhibits progesterone production. Nature 282, 90-92.

Clermont, Y. (1972). Kinetics of spermatogenesis in mammals: seminiferous epithelium cycle and spermatogonial renewal. Physiol. Rev. 52, 198-236.

D’Antonio, M., Fasano, S., de Leeuw, R., and Pierantoni, R. (1992). Effects of gonadotropin-releasing hormone variants on plasma and testicular androgen levels in intact and hypophysectomized male frogs, Rana esculenta. J. Exp. Zool. 261, 34-39.

Davis, J. S., West, L. A., and Farese, R. V. (1986). Gonadotropin-releasing hormone $(\mathrm{GnRH})$ rapidly stimulates the formation of inositol phosphates and diacyglycerol in rat granulosa cells: further evidence for the involvement of $\mathrm{Ca} 2+$ and protein kinase $\mathrm{C}$ in the action of GnRH. Endocrinology 118, 2561-2571.

Di Fiore, M.M., Rastogi, R. K., Ceciliani, F., Messi, E., Botte, V., Botte, L., Pinelli, C., D'Aniello, B., and D'Aniello, A. (2000). Mammalian and chicken I forms of gonadotropin-releasing hormone in the gonads of a protochordate, Ciona intestinalis. Proc. Natl. Acad. Sci. U.S.A. 97, 2343-2348.

Di Matteo, L., Vallarino, M., and Pierantoni, R. (1996). Localization of $\mathrm{GnRH}$ molecular forms in the brain, pituitary, and testis of the frog, Rana esculenta. J. Exp. Zool. 274, 33-40.

Dong, K. W., Duval, P., Zeng, Z., Gordon, K., Williams, R. F., Hodgen, G. D., Jones, G., Kerdelhue, B., and Roberts, J.
L. (1996). Multiple transcription start sites for the GnRH gene in rhesus and cynomolgus monkeys: a non-human primate model for studying GnRH gene regulation. Mol. Cell. Endocrinol. $117,121-130$.

Ducret,E.,Anderson, G.M., and Herbison, A. E. (2009). RFamide-related peptide- 3 , amammalian gonadotropin-inhibitory hormone ortholog, regulates gonadotropin-releasing hormone neuron firing in the mouse. Endocrinology 150, 2799-2804.

Dufau, M. L., and Knox, G. F. (1985). Fetal Leydig cell culture-an in vitro system for the study of trophic hormone and GnRH receptors and actions. J. Steroid Biochem. 23, 743-755.

El-Gehani, F., Tena-Sempere, M., and Huhtaniemi, I. (1998). Vasoactive intestinal peptide stimulates testosterone production by cultured fetal rat testicular cells. Mol. Cell. Endocrinol. 140, 175-178.

Endo, D., and Park, M. K. (2004). Molecular characterization of the leopard gecko POMC gene and expressional change in the testis by acclimation to low temperature and with a short photoperiod. Gen. Comp. Endocrinol. 138, 70-77.

Ferin, M. (1999). Clinical review 105: stress and the reproductive cycle. J. Clin. Endocrinol. Metab. 84, 1768-1774.

Florio, P., Vale, W., and Petraglia, F. (2004). Urocortins in human reproduction. Peptides 25, 1751-1757.

Gann, P. H., Hennekens, C. H., Ma, J., Longcope, C., and Stampfer, M. J. (1996). Prospective study of sex hormone levels and risk of prostate cancer. J. Natl. Cancer Inst. 88, 1118-1126.

Garcia-Reyero, N., Villeneuve, D. L., Kroll, K. J., Liu, L., Orlando, E. F., Watanabe, K. H., Sepúlveda, M. S., Ankley, G. T., and Denslow, N.D. (2009). Expression signatures for a model androgen and antiandrogen in the fathead minnow (Pimephales promelas) ovary. Environ. Sci. Technol. 43, 2614-2619.

Gazourian, L., Deragon, K. L., Chase, C. F., Pati, D., Habibi, H. R., and Sower, S. A. (1997). Characteristics of GnRH binding in the gonads and effects of lamprey GnRH-I and -III on reproduction in the adult sea lamprey. Gen. Comp. Endocrinol. 108, 327-339.

Gazourian, L., Evans, E. L., Hanson, L., Chase, C. F., and Sower, S. A. (2000). The effects of lamprey GnRH-I, -III and analogs on steroidogenesis in the sea lamprey (Petromyzon marinus). Aquaculture 188, 147-165.

Geris, K. L., Meeussen, G., Kühn, E. R., and Darras, V. M. (2000). Distribution of somatostatin in the brain and of somatostatin and thyrotropin-releasing hormone in peripheral tissues of the chicken. Brain Res. 873, 306-309.
Gore-Langton, R. E., Lacroix, M., and Dorrington, J. H. (1981). Differential effects of luteinizing hormone-releasing hormone on follicle-stimulating hormone-dependent responses in rat granulosa cells and Sertoli cells in vitro. Endocrinology 108, 812-819.

Gougeon, A. (1996). Regulation of ovarian follicular development in primates: Facts and hypotheses. Endocr. Rev. 17, 121-155.

Grober,M.S., Myers, T.R., Marchaterre,M. A., Bass, A. H., and Myers, D. A. (1995). Structure, localization, and molecular phylogeny of a GnRH cDNA from a paracanthopterygian fish, the plainfin midshipman (Porichthys notatus). Gen. Comp. Endocrinol. 99, 85-99.

Gründker, C., Günthert, A. R., Millar, R. P., and Emons, G. (2002). Expression of gonadotropin-releasing hormone II (GnRH-II) receptor in human endometrial and ovarian cancer cells and effects of GnRH-II on tumor cell proliferation. J. Clin. Endocrinol. Metab. 87, 1427-1430.

Gupta, G., Maikhuri, J. P., Setty, B. S., and Dhar, J. D. (2000). Seasonal variations in daily sperm production rate of rhesus and bonnet monkeys. J. Med. Primatol. 29, 411-414.

Heinrich, N., Meyer, M. R., Furkert, J., Sasse, A., Beyermann, M., Bönigk, W. and Berger, H. (1998). Corticotropinreleasing factor (CRF) agonists stimulate testosterone production in mouse leydig cells through CRF receptor-1. Endocrinoly 139, 651-658.

Hertelendy, F., Lintner, F., Asem, E. K., and Raab, B. (1982). Synergistic effect of gonadotropin releasing hormone on LH-stimulated progesterone production in granulosa cells of the domestic fowl (Gallus domesticus). Gen. Comp. Endocrinol. 48, 117-122.

Hinuma, S., Shintani, Y., Fukusumi, S., Iijima, N., Matsumoto, Y., Hosoya, M., Fujii, R., Watanabe, T., Kikuchi, K., Terao, Y., Yano, T., Yamamoto, T., Kawamata, Y., Habata, Y., Asada, M., Kitada, C., Kurokawa, T., Onda, H., Nishimura, O., Tanaka, M., Ibata, Y., and Fujino, M. (2000). New neuropeptides containing carboxy-terminal RFamide and their receptor in mammals. Nat. Cell Biol. 2, 703-708.

Hsueh, A. J., Bambino, T. H., Zhuang, L. Z., Welsh, T. H. Jr., and Ling, N. C. (1983). Mechanism of the direct action of gonadotropin-releasing hormone and its antagonist on androgen biosynthesis by cultured rat testicular cells. Endocrinology 112, 1653-1661.

Hsueh, A. J., and Erickson, G. F. (1979). Extra-pituitary inhibition of testicular function by luteinising hormone releasing hormone. Nature 81, 66-67.

Hsueh, A. J., and Jones, P. B. (1981). Extrapituitary actions of 
gonadotropin-releasing hormone. Endocr. Rev. 2, 437-461.

Hsueh, A. J., Schreiber, J. R., and Erickson, G. F. (1981). Inhibitory effect of gonadotropin releasing hormone upon cultured testicular cells. Mol. Cell. Endocrinol. 21, 43-49.

Hsueh, A. J., Wang, C., and Erickson, G. F. (1980). Direct inhibitory effect of gonadotropin-releasing hormone upon follicle-stimulating hormone induction of luteinizing hormone receptor, and aromatase activity in rat granulosa cells. Endocrinolgy 106, 1697-1705.

Huang, B. M., Stocco, D. M., Hutson, J. C., and Norman, R. L. (1995). Corticotropin-releasing hormone stimulates steroidogenesis in mouse Leydig cells. Biol. Reprod. 53, 620-626.

Hubbard, G. M., and Licht, P. (1985). In vitro study of the direct ovarian effects of gonadotropin-releasing hormone $(\mathrm{GnRH})$ in the frogs, Rana pipiens and Rana catesbeiana. Gen. Comp. Endocrinol. 60, 154-161.

Ikemoto, T., and Park, M. K. (2007). Comparative analysis of the pituitary and ovarian GnRH systems in the leopard gecko: signaling crosstalk between multiple receptor subtypes in ovarian follicles. J. Mol. Endocrinol. 38, 289-304.

Irusta, G., Parborell, F., and Tesone, M. (2007). Inhibition of cytochrome P-450 C17 enzyme by a GnRH agonist in ovarian follicles from gonadotropin-stimulated rats. Am. J. Physiol. Endocrinol. Metab. 292, E1456-E1464.

Johnson, A. L., and Tilly, J. L. (1988). Effects of vasoactive intestinal peptide on steroid secretion and plasminogen activator activity in granulosa cells of the hen. Biol. Reprod. 38, 296-303.

Johnson, M. A., Tsutsui, K., and Fraley, G. S. (2007). Rat RFamide-related peptide-3 stimulates GH secretion, inhibits LH secretion, and has variable effects on sex behavior in the adult male rat. Horm. Behav. 51, 171-180.

Jones, P. B., Conn, P. M., Marian, J., and Hsueh, A. J. (1980). Binding of gonadotropin releasing hormone agonist to rat ovarian granulose cells. Life Sci. $27,2125-2132$.

Jones, P. B., and Hsueh, A. J. (1981). Direct effects of gonadotropin releasing hormone and its antagonist upon ovarian functions stimulated by FSH, prolactin, ans LH. Biol. Reprod. 24, 747.

Kang, S. K., Tai, C. J., Cheng, K. W., and Leung, P. C. (2000). Gonadotropinreleasing hormone activates mitogenactivated protein kinase in human ovarian and placental cells. Mol. Cell. Endocrinol. 170, 143-151.

Kang, S. K., Tai, C. J., Nathwani, P. S., and Leung, P. C. (2001). Differential regulation of two forms of gonadotropin-releasing hormone messenger ribonucleic acid in human granulosa-luteal cells. Endocrinolgy 142, 182-192.

Kawada, T., Sekiguchi, T., Itoh, Y., Ogasawara, M., and Satake, $\mathrm{H}$. (2008). Characterization of a novel vasopressin/oxytocin superfamily peptide and its receptor from an ascidian, Ciona intestinalis. Peptides 29, 1672-1678.

Kawashima, M., Takahashi, T., Yasuoka, T., Kamiyoshi, M., and Tanaka, K. (1995). A vasoactive intestinal peptide binding component in hen granulose cells. Proc. Soc. Exp. Biol. Med. 209, 387-391.

Kopp, J., Zhang, X., and Hökfelt, T. (1997). Neuropeptide Y1 receptors in the rat genital tract. Regul. Pept. 70, 149-160.

Kriegsfeld, L. J., Mei, D. F., Bentley, G. E., Ubuka, T., Mason, A. O., Inoue, K., Ukena, K., Tsutsui, K., and Silver, R. (2006). Identification and characterization of a gonadotropin-inhibitory system in the brains of mammals. Proc. Natl. Acad. Sci. U.S.A. 103, 2410-2415.

Lin, X. W., and Peter, R. E. (1996). Expression of salmon gonadotropinreleasing hormone (GnRH) and chicken GnRH-II precursor messenger ribonucleic acids in the brain and ovary of goldfish. Gen. Comp. Endocrinol. 101, 282-296.

MacDonald, E., and Volkoff, H. (2009). Neuropeptide Y (NPY), cocaine- and amphetamine-regulated transcript (CART) and cholecystokinin (CCK) in winter skate (Raja ocellata): cDNA cloning, tissue distribution and mRNA expression responses to fasting. Gen. Comp. Endocrinol. 161, 252-261.

Maddineni, S. R., Ocón-Grove, O. M., Krzysik-Walker, S. M., and Hendricks, G. L. 3rd, Ramachandran, R. (2008). Gonadotropin-inhibitory hormone $(\mathrm{GnIH})$ receptor gene is expressed in the chicken ovary: potential role of $\mathrm{GnIH}$ in follicular maturation. Reproduction 135, 267-274.

Madigou, T., Uzbekova, S., Lareyre, J. J., and Kah, O. (2002). Two messenger RNA isoforms of the gonadotrophinreleasing hormone receptor, generated by alternative splicing and/or promoter usage, are differentially expressed in rainbow trout gonads during gametogenesis. Mol. Reprod. Dev. 63, 151-160.

Masini, M. A., Sturla, M., Pestarino, M., Gallinelli, A., Facchinetti, F., and Uva, B. M. (1997). Pro-opiomelanocortin (POMC) expression and immunolocalization of POMC-related peptides in the ovary of Protopterus annectens, an African lungfish. Peptides 18, 1411-1414.
McGuire, N. L., and Bentley, G. E. (2010). A functional neuropeptide system in vertebrate gonads: Gonadotropininhibitory hormone and its receptor in testes of field-caught house sparrow (Passer domesticus). Gen. Comp. Endocrinol. 166, 565-572.

McGuire, N. L., Kangas, K. K, and Bentley, G. E. (2010). Direct regulation of the gonadal GnIH system and steroid biosynthesis in the European starling (Sturnus vulgaris) testes and ovary by melatonin. Endocrinology (Submitted).

McRory, J. E., Parker, D. B. Ngamvongchon, S., and Sherwood, N. M. (1995). Sequence and expression of cDNA for pituitary adenylate cyclase activating polypeptide (PACAP) and growth hormonereleasing hormone (GHRH)like peptide in catfish. Mol. Cell. Endocrinol. 108, 169-177.

Millar, R., Lowe, S., Conklin, D., Pawson, A., Maudsley, S., Troskie, B., Ott, T., Millar, M., Lincoln, G., Sellar, R., Faurholm, B., Scobie, G., Kuestner, R., Terasawa, E., and Katz, A. (2001). A novel mammalian receptor for the evolutionarily conserved type II GnRH. Proc. Natl. Acad. Sci. U.S.A. 98, 9636-9641.

Minucci, S., Di Matteo, L., Pierantoni R., Varriale, B., Rastogi, R. K., and Chieffi, G. (1986). In vivo and in vitro stimulatory effect of a gonadotropinreleasing hormone analog (HOE 766) on spermatogonial multiplication in the frog, Rana esculenta. Endocrinology 119, 731-736.

Moumni, M., Kottler, M. L., and Counis, R. (1994). Nucleotide sequence analysis of mRNA predicts that rat pituitary and gonadal gonadotropin-releasing hormone receptor proteins have identical primary structure. Biochem. Biophys. Res. Commun.. 200, 1359-1366.

Neill, J. D. (2002). GnRH and GnRH receptor genes in the human genome. Endocrinology 143, 737-743.

Nicholson, H. D., Swann, R. W., Burford, G. D., Wathes, D. C., Porter, D. G., and Pickering, B. T. (1984). Identification of oxytocin and vasopressin in the testis and in adrenal tissue. Regul. Pept. 8, 141-146.

Ohta, M., Funakoshi, S., Kawasaki, T., and Itoh, N. (1992). Tissue-specific expression of the rat secretin precursor gene. Biochem. Biophys. Res. Commun. 183, 390-395.

Oikawa, M., Dargan, C., Ny, T., and Hsueh, A. J. (1990). Expression of gonadotropin-releasing hormone and prothymosin-alpha messenger ribonucleic acid in the ovary. Endocrinology 127, 2350-2356.

Osugi, T., Ukena, K., Bentley, G.E., O’Brien, S., Moore, I. T., Wingfield, J. C., and
Tsutsui, K. (2004). Gonadotropininhibitory hormone in Gambel's white-crowned sparrow (Zonotrichia leucophrys gambelii): cDNA identification, transcript localization and functional effects in laboratory and field experiments. J. Endocrinol. 182, 33-42.

Pati, D., and Habibi, H. R. (1998). Presence of salmon gonadotropin-releasing hormone $(\mathrm{GnRH})$ and compounds with GnRH-like activity in the ovary of goldfish. Endocrinology 139, 2015-2024.

Pati, D., and Habibi, H. R. (2000). Direct action of GnRH variants on goldfish oocyte meiosis and follicular steroidogenesis. Mol. Cell. Endocrinol. 160, 75-88.

Paull, W. K., Turkelson, C. M., Thomas, C. R., and Arimura, A. (1981). Immunohistochemical demonstration of a testicular substance related to luteinizing hormone-releasing hormone. Science 213, 1263-1264.

Pazos, A. J., and Mathieu, M. (1999). Effects of five natural gonadotropinreleasing hormones on cell suspensions of marine bivalve gonad: stimulation of gonial DNA synthesis. Gen. Comp. Endocrinol. 113, 112-120.

Pekary, A. E., Meyer, N.V., Vaillant, C., and Hershman, J.M. (1980). Thyrotropinreleasing hormone and a homologous peptide in the male rat reproductive system. Biochem. Biophys. Res. Commun. 95, 993-1000.

Peng, C., Fan, N.C., Ligier, M., Väänänen, J., and Leung, P. C. (1994). Expression and regulation of gonadotropinreleasing hormone $(\mathrm{GnRH})$ and GnRH receptor messenger ribonucleic acids in human granulosa-luteal cells. Endocrinology 135, 1740-1746.

Pineda, R., Garcia-Galiano, D., SanchezGarrido,M.A., Romero, M., Ruiz-Pino, F.,Aguilar, E., Dijcks, F.A., Blomenröhr, M., Pinilla, L., van Noort, P. I., and TenaSempere, M. (2010). Characterization of the potent gonadotropin-releasing activity of RF9, a selective antagonist of RF-amide-related peptides and neuropeptide FF receptors: physiological and pharmacological implications. Endocrinology 151, 1902-1913.

Pintar, J. E., Schachter, B. S., Herman, A. B., Durgerian, S., and Krieger, D. T. (1984). Characterization and localization of proopiomelanocortin messenger RNA in the adult rat testis. Science 225, 632-634.

Powell, J.F., Reska-Skinner, S. M., Prakash, M. O., Fischer, W. H., Park, M., Rivier, J. E., Craig, A. G., Mackie, G. O., and Sherwood, N. M. (1996). Two new forms of gonadotropin-releasing hormone in a protochordate and the evolutionary implications. Proc. Natl. Acad. Sci. U.S.A. 93, 10461-10464. 
Riesen, J. W., Meyer, R. K., and Wolf, R. C. (1971). The effect of season on occurrence of ovulation in the rhesus monkey. Biol. Reprod. 5, 111-114.

Roberts, M. L., Buchanan, K. L., Hasselquist, D., and Evans, M. R. (2007). Effects of testosterone and corticosterone on immunocompetence in the zebra finch. Horm. Behav. 51, 126-134.

Romanelli, F., Fillo, S., Isidori, A., Gaudino, S., and Conte, D. (1998). Galanin stimulates steroidogenesis in rat Leydig cells. Life Sci. 63, 255-263.

Sari, I. P., Rao, A., Smith, J. T., Tilbrook, A. J., and Clarke, I. J. (2009). Effect of RF-amide-related peptide- 3 on luteinizing hormone and follicle-stimulating hormone synthesis and secretion in ovine pituitary gonadotropes. Endocrinology 150, 5549-5556.

Schally, A. V. (1999). Luteinizing hormone-releasing hormone analogs: their impact on the control of tumorigenesis. Peptides 20, 1247-1262.

Schally, A. V., Arimura, A., Kastin, A. J., Matsuo, H., Baba, Y., Redding, T. W., Nair, R. M., Debeljuk, L., and White, W. F. (1971). Gonadotropin-releasing hormone: one polypeptide regulates secretion of luteinizing and folliclestimulating hormones. Science 173, 1036-1038.

Schirman-Hildesheim, T. D., Bar, T., Ben-Aroya, N., and Koch, Y. (2005). Differential gonadotropin-releasing hormone (GnRH) and GnRH receptor messenger ribonucleic acid expression patterns in different tissues of the female rat across the estrous cycle. Endocrinology 146, 3401-3408.

Schirman-Hildesheim, T. D., Ben-Aroya, N., and Koch, Y. (2006). Daily GnRH and $\mathrm{GnRH}$-receptor mRNA expression in the ovariectomized and intact rat. Mol. Cell. Endocrinol. 252, 120-125.

Schmidt, K. L., Pradhan, D. S., Shah, A. H., Charlier, T. D., Chin, E. H., and Soma, K. K. (2008). Neurosteroids, immunosteroids, and the Balkanization of endocrinology. Gen. Comp. Endocrinol. 157, 266-274.

Schulze, W., Davidoff, M. S., and Holstein, A. F. (1987). Are Leydig cells of neural origin? Substance P-like immunoreactivity in human testicular tissue. Acta Endocrinol. 115, 373-377.

Shahed A., and Young, K. A. (2009). Differential ovarian expression of KiSS-1 and GPR-54 during the estrous cycle and photoperiod induced recrudescence in siberian hamsters (Phodopus sungorus). Mol. Reprod. Dev. 76, 444-452.

Sharpe, R. M., Doogan, D. G., and Cooper, I. (1982). Stimulation of Leydig cell testosterone secretion in vitro and in vivo in hypophysectomized rats by an agonist of luteinizing hormone releasing hormone. Biochem. Biophys. Res. Commun. 106, 1210-1217.

Shen, S. T., Lu, L. M., Chen, J. R., Chien, J. T., and Yu, J.Y. (2003). Molecular cloning of proopiomelanocortin (POMC) cDNA from mud turtle, Pelodiscus sinensis. Gen. Comp. Endocrinol. 131, 192-201.

Shimizu, M., and Bédécarrats, G. Y. (2010). Activation of the chicken gonadotropin-inhibitory hormone receptor reduces gonadotropin releasing hormone receptor signaling. Gen. Comp. Endocrinol. 67, 331-337.

Singh, P., Krishna, A., and Sridaran, R. (2007).Localization of gonadotrophinreleasing hormone I, bradykinin and their receptors in the ovaries of nonmammalian vertebrates. Reproduction 133, 969-981.

Stewart, A. J., Katz, A. A., Millar, R. P., and Morgan, K. (2009). Retention and silencing of prepro-GnRH-II and type II GnRH receptor genes in mammals. Neuroendocrinology 90, 416-432.

Sun, Y. M., Dunn, I. C., Baines, E., Talbot, R. T., Illing, N., Millar, R. P., and Sharp, P. J. (2001). Distribution and regulation by oestrogen of fully processed and variant transcripts of gonadotropin releasing hormone I and gonadotropin releasing hormone receptor mRNAs in the male chicken. J. Neuroendocrinol. 13, 37-49.

Takekida, S., Matsuo, H., and Maruo, T. (2003). GnRH agonist action on granulosa cells at varying follicular stages. Mol. Cell. Endocrinol. 202, 155-164.

Takeuchi, S., Teshigawara, K., and Takahashi, S. (1999). Molecular cloning and characterization of the chicken pro-opiomelanocortin (POMC) gene. Biochim. Biophys. Acta 1450, 452-459.

Terado, M., Nomura, M., Mineta, K., Fujimoto, N., and Matsumoto, T. (2006). Expression of neuropeptide $\mathrm{Y}$ gene in mouse testes during testicular development. Asian J. Androl. 8, 443-449.

Tsutsui, K., Bentley, G. E., Ubuka, T., Saigoh, E., Yin, H., Osugi, T., Inoue, K., Chowdhury, V.S., Ukena, K., Ciccone, N., Sharp, P. J., and Wingfield, J. C. (2007). The general and comparative biology of gonadotropin-inhibitory hormone (GnIH). Gen. Comp. Endocrinol. 153, 365-370.

Tsutsui, K., Saigoh, E., Ukena, K., Teranishi, H., Fujisawa, Y., Kikuchi, M., Ishii, S., and Sharp, P. J. (2000). A novel avian hypothalamic peptide inhibiting gonadotropin release.
Biochem. Biophys. Res. Commun. 275, 661-667.

Tsutsui, K., Saigoh, E., Yin, H., Ubuka,T., Chowdhury, V. S., Osugi, T., Ukena, K., Sharp, P. J., Wingfield, J. C., and Bentley, G. E. (2009). A new key neurohormone controlling reproduction, gonadotropin-inhibitory hormone (GnIH) in birds: discovery, progress and prospect. J. Neuroendocrinol. 21, 271-275.

Tsutsui, K., and Ukena, K. (2006). Hypothalamic LPXRF-amide peptides in vertebrates: identification, localization and hypophysiotropic activity. Peptides 1121-1129.

Ubuka, T, Morgan, K., Pawson, A. J., Osugi, T., Chowdhury, V. S., Minakata, H., Tsutsui, K., Millar, R. P., and Bentley, G. E. (2009). Identification of human GnIH homologs, RFRP-1 and RFRP-3, and the cognate receptor, GPR147 in the human hypothalamic pituitary axis. PLoS ONE 4, e8400. doi:10.1371/ journal.pone.0008400.

Ubuka, T., Ukena, K., Sharp, P. J., Bentley, G. E., and Tsutsui, K. (2006). Gonadotropin-inhibitory hormone inhibits gonadal development and maintenance by decreasing gonadotropin synthesis and release in male quail. Endocrinolgy 147, 1187-1194.

Vaccari, S., Latini, S., Barberi, M., Teti, A. Stefanini, M., and Canipari, R. (2006). Characterization and expression of different pituitary adenylate cyclaseactivating polypeptide/vasoactive intestinal polypeptide receptors in rat ovarian follicles. J. Endocrinol. 191, 287-299.

Vermeulen, A. (1993). Environment, human reproduction, menopause, and andropause. Environ. Health Perspect. 101(Suppl. 2), 91-100.

Vigersky, R. A., Andersen, A. E., Thompson, R. H., and Loriaux, D. L. (1977). Hypothalamic dysfunction in secondary amenorrhea associated with simple weight loss. N. Engl. J. Med. 297, 1141-1145.

von Schalburg, K. R., Harrower, W. L., and Sherwood, N. M. (1999). Regulation and expression of gonadotropinreleasing hormone in salmon embryo and gonad. Mol. Cell. Endocrinol. 157, 41-54.

Waser, B., Rehmann, R., Rivier, J., Vale, W., and Reubi, J. C. (2006). CRF receptors in the rodent and human cardiovascular systems: species differences. Peptides 27, 3029-3038.

Weinbauer, G. F., Surmann, F. J., Akhtar, F. B., Shah, G. V., Vickery, B. H., and Nieschlag, E. (1984). Reversible inhibition of testicular function by a gonadotropin hormone-releasing hormone antagonist in monkeys (Macaca fascicularis). Fertil. Steril. 42, 906-914.

Whitelaw, P. F., Eidne, K. A., Sellar, R., Smyth, C. D., and Hillier, S. G. (1995). Gonadotropin-releasing hormone receptor messenger ribonucleic acid expression in rat ovary. Endocrinology 136, 172-179.

Wingfield, J. C., Ukena, K., Tsutsui, K., and Bentley, G. E. (2004). Photoperiod effects on plasma gonadotropin-inhibitory hormone $(\mathrm{GnIH})$, and evidence for peripheral $\mathrm{GnIH}$ binding sites in white-crowned sparrows. Abstract 885.9 presented at the 34th Annual Meeting for the Society for Neuroscience, San Diego, CA.

Yin, H., Ukena, K., Ubuka, T., and Tsutsui, K. (2005). A novel G protein-coupled receptor for gonadotropin-inhibitory hormone in the Japanese quail (Coturnix japonica): identification, expression and binding activity. $J$. Endocrinol. 184, 257-266.

Zhao, S., Saito, H., Wang, X., Saito, T., Kaneko, T., and Hiroi, M. (2000). Effects of gonadotropin-releasing hormone agonist on the incidence of apoptosis in porcine and human granulosa cells. Gynecol. Obstet. Invest. 49, 52-56.

Zhao, S., Zhu, E., Yang, C., Bentley, G. E., Tsutsui, K., and Kriegsfeld, L. J. (2010). RFamide-related peptide and messenger ribonucleic acid expression in mammalian testis: association with the spermatogenic cycle. Endocrinology 151, 617-627.

Conflict of Interest Statement: The authors declare that the research was conducted in the absence of any commercial or financial relationships that could be construed as a potential conflict of interest.

Received: 18 May 2010; paper pending published: 20 June 2010; accepted: 07 August 2010; published online: 09 September 2010.

Citation: McGuire NL and Bentley GE (2010) Neuropeptides in the gonads: from evolution to pharmacology. Front. Pharm. 1:114. doi: 10.3389/fphar.2010.00114 This article was submitted to Frontiers in Integrative Pharmacology, a specialty of Frontiers in Pharmacology.

Copyright (C) 2010 McGuire and Bentley. This is an open-access article subject to an exclusive license agreement between the authors and the Frontiers Research Foundation, which permits unrestricted use, distribution, and reproduction in any medium, provided the original authors and source are credited. 